\title{
Electron crystallography of protein nano-crystals
}

\section{Igor Nederlof $^{1}$}

${ }^{1}$ Amsterdam Scientific Instruments B.V., Amsterdam, Netherlands E-mail: igor.nederlof@amscins.com

Sub-micron protein crystals are beyond the range of standard X-ray diffraction experiments. Many proteins however fail to grow large, diffraction grade, crystals due to stacking faults. Using electron diffraction the structure can be solved of crystals that are 1-2 orders of magnitude smaller than what is standard using X-rays. In this talk I will show 3D electron crystallography data and the solved structure of lysozyme. I will touch on the possibilities and limitation of this new method and show recent advances in detector hardware that have enabled this exciting new field.

[1]. R. Henderson; Q. Rev. Biophys. 28, 171 (1995)

[2]. Nederlof, I., van Genderen, E., Li, Y.-W. \& Abrahams, J. P. (2013). Acta Cryst. D69, 1223-1230

[3]. Nederlof, I., Li, Y. W., van Heel, M. \& Abrahams, J. P. (2013). Acta Cryst. D69, 852-859.

[4]. Nederlof I.; Protein Crystallography by Diffraction and Imaging. PhD Thesis

[5]. van Genderen, E., Clabbers, M. T. B., Das, P. P., Stewart, A., Nederlof, I., Barentsen, K. C., Portillo, Q., Pannu, N. S., Nicolopoulos, S., Gruene, T. \& Abrahams, J. P. (2016). Acta Cryst. A72, 236-242

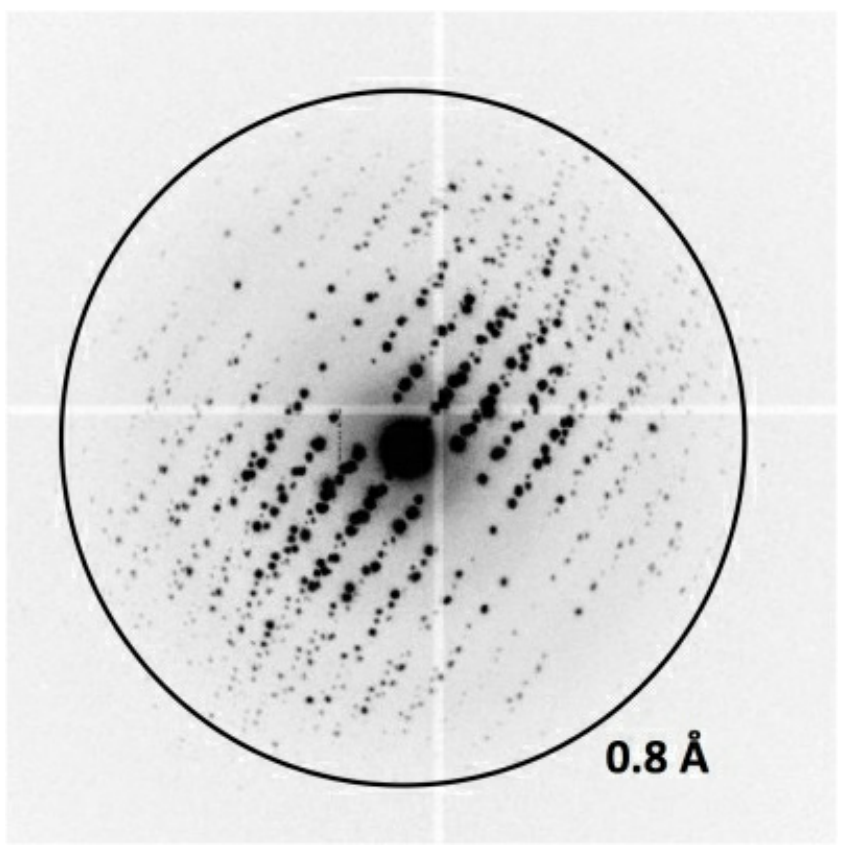

Keywords: Electron Diffraction, Protein, Nano-Crystals 